\title{
МАТВЕЙ НИКОЛАЕВИЧ ЕРШОВ: ВОЗВРАЩЕНИЕ ФИЛОСОФА
}

\author{
DOI dx.doi.org/10.24866/1997-2857/2020-2/128-137
}

\author{
«...ИМЕЕМ ЧЕСТЬ ПРЕДЛОЖИТЬ ФАКУЛЬТЕТУ»: \\ ОТЗЫВ ОБ АКАДЕМИЧЕСКОЙ ДЕЯТЕЛЬНОСТИ \\ И УЧЕНЫХ РАБОТАХ ПРОФЕССОРА М.Н. ЕРШОВА
}

\author{
Подготовка к публикации и комментарии О.П. Еланцевой и П.А. Щербина*
}

«Отзыв об академической деятельности и ученых работах профессора Матвея Николаевича Ершова» представляет несомненную ценность для всех, кто интересуется жизнью и деятельностью М.Н. Ершова, а также историей отечественной академической среды. Он интересен уже потому, что позволяет увидеть, по каким параметрам сто лет назад оценивалась трудовая деятельность вузовского преподавателя, профессора, каким был стиль подобных характеристик. Кроме того, документ дает возможность сравнить, насколько изменился (и изменился ли) взгляд на творчество М.Н. Ершова за прошедшее столетие. Вместе с тем, в документе в части описания биографии профессора дважды встречается фраза «обстоятельства времени заставили/принудили» сначала покинуть Казань в 1918 г., а затем остаться во Владивостоке в 1919 г. Это очень краткое объяснение ярко высвечивает судьбу М.Н. Ершова как одного из многих, вынужденных выстраивать свою жизнь в хаосе революции и гражданской войны, и выводит на проблему практик адаптации к этим социально-политическим потрясениям.

«Отзыв» включает несколько частей лаконичного, отточенного текста. В начальной раскрыты главные ступени профессионального роста, достигнутые М.Н. Ершовым в Казани и Владивостоке, где он инициировал создание историко-филологического факультета, затем стал его деканом, а по кафедре философии вел преподавание нескольких основных и дополнительных курсов. В «Отзыве» отмечено, что М.Н. Ершов отдал «много времени, энергии и здоровья» решению задач по учреждению Государственного дальневосточного университета. Во вновь открытом в апреле 1920 г. ГДУ Матвей Николаевич Ершов был избран на должность проректора.

В основной части «Отзыва» содержится характеристика научных трудов М.Н. Ершова: диссертации о философии Мальбранша и целого ряда статей по этому же предмету. Здесь же дается их оценка и указываются некоторые отличительные особенности, которые делали сочинения М.Н. Ершова «особенно ценными и значительными для нашей науки». В документе присутствует и характеристика М.Н. Ершова-преподавателя, академического работника.

Последняя часть «Отзыва» ограничивается Списком трудов профессора - как уже изданных, так и подготовленных или готовящихся к печати.

Текст «Отзыва об академической деятельности и ученых работах профессора Матвея Николаевича Ершова» выявлен в разных вариантах в нескольких архивах. Во-первых, в двух делах фонда Дальневосточного государственного университета в Российском государственном историческом архиве Дальнего Востока (РГИА

* ЕЛАНЦЕВА Ольга Павловна, доктор исторических наук, профессор Департамента истории и археологии Школы искусств и гуманитарных наук Дальневосточного федерального университета.

E-mail: elantseva.op@dvfu.ru

ЩЕРБИНА Полина Анатольевна, кандидат исторических наук, доцент Департамента истории и археологии Школы искусств и гуманитарных наук Дальневосточного федерального университета.

E-mail: scherbina.pa@dvfu.ru

(C) Еланцева О.П., Щербина П.А., 2020 
ДВ. Ф. Р-289. Оп. 1. Д. 73; Д. 97), во-вторых, в Архиве востоковедов Института восточных рукописей РАН (АВ ИВР РАН. Ф. 96. Д. 102), в фонде А.В. Рудакова ${ }^{1}$.

Документы не идентичны, различаются степенью полноты текста, присутствуют некоторые отличия в используемых словосочетаниях, расстановке знаков препинания. Все три являются машинописными копиями, каждая из которых отличается шрифтом и размером букв, установленными на страницах полями, форматом бумаги и т.д. Ни на одном из трех документов не проставлена дата. Отсутствуют сведения об авторстве.

Публикуемый текст - наиболее полный из трех выявленных, имеет заключительное положение, определяющее целевое назначение документа: представление к назначению на должность. В деле документ сопровожден копией отзыва С.Л. Франка из журнала «Русская мысль» [2] на диссертацию М.Н. Ершова «Проблема богопознания в философии Мальбранша» (РГИА ДВ. Ф. Р-289. Оп. 1. Д. 97. Л. 13-14).

Заключительное положение «Отзыва» позволяет сделать предположение о времени создания документа: «На основании всего вышеизложенного и имея в виду пункт 5-й ст. 3 “Временного положения о Государственном Дальневосточном Университете”2, мы имеем честь предложить факультету возбудить ходатайство через Совет Университета перед Временным правительством ${ }^{3}$ о назначении профессора М.Н. Ершова и.д. ординарного профессора по кафедре философии».

Можно предположить, что «Отзыв» появился не ранее дня учреждения ГДУ и утверждения «Временного положения о Государственном Дальневосточном Университете». Факультеты ГДУ получили право предлагать распределять преподавательские должности, руководствуясь пятью основаниями. Одно из них стало приемлемым для Матвея Николаевича Ершова. Долж-

1 Рудаков Аполлинарий Васильевич (18711949) - востоковед-китаист, профессор, директор Восточного института. В 1920-1939 гг. - профессор, зав. кафедрой китайского языка в ГДУ-ДВГУ.

217 апреля 1920 г. Приморская Земская Управа приняла Постановление № 220 об учреждении Государственного Дальневосточного университета и приложение к нему «Временное положение о государственном дальневосточном университете» [1, c. 280-284].

${ }^{3}$ Речь идет о Временном Правительстве Дальнего Востока - Приморской Земской Управе. ность ординарного профессора он не мог занять по причине отсутствия у него ученой степени доктора, а вот «исправлять должность ординарного профессора» обстоятельства позволяли, так как сюда были «допускаемы лица, удовлетворяющие требованиям, предъявляемым к экстраординарным профессорам» [1, с. 281].

При подготовке документа к печати орфография оригинала сохранена в случаях использования специальных терминов и характеристик; унифицировано сокращение «год»- «г.», «век»- «в.»; некоторые сокращения, использованные в оригинале, даны полностью: «например», «город», «профессор».

\section{СПИСОК ЛИТЕРАТУРЫ}

1. История Дальневосточного государственного университета в документах и материалах. 1899-1939 гг. Владивосток: Дальнаука, 2004.

2. Русская мысль. 1915. Кн. ХІ.

\section{REFERENCES}

1. Istoriya Dal'nevostochnogo gosudarstvennogo universiteta $\mathrm{v}$ dokumentakh i materialakh. 1899-1939 gg. [The history of the Far Eastern State University in documents and materials. 18991939]. Vladivostok: Dal'nauka, 2004. (in Russ.)

2. Russkaya mys1, 1915, book XI. (in Russ.)

\section{отзыв \\ об академической деятельности \\ и ученых работах профессора \\ Матвея Николаевича Ершова}

I. Матвей Николаевич Ершов родился 1 августа 1886 г. В 1911 г. он окончил Казанскую Духовную Академию первым магистрантом и был оставлен при Академии для подготовления к профессорскому званию. С осени 1912 г. М.Н. Ершов уже - исправляющий должность доцента Казанской Духовной академии. В течение 3-х лет М.Н. Ершов пишет свою диссертацию (которая по своим заданиям и плану потребовала разработки чрезвычайно обширного материала, подробного изучения нескольких труднейших для понимания эпох истории философии) и одновременно читает курсы по древней и новой философии и руководит практическими занятиями по разным отделам философии. В 1914 г. он защищает свою магистерскую диссертацию «Проблема богопознания в философии Мальбранша» и затем утверждается в звании доцента Академии. 
По прошествии четырех лет ученой и педагогической деятельности М.Н. Ершов был избран 7 мая 1916 г. экстраординарным профессором Академии, а 29 декабря того же года приват-доцентом Казанского университета. В Академии профессор Ершов занял кафедру истории философии, по каковой и читал как основные, так и дополнительные курсы, исполняя в то же время различные поручения Совета Академии ученого и академического характера, как, например, рецензирование докторской диссертации профессора Галахова ${ }^{4}$, чтение и рецензирование студенческих и кандидатских сочинений и т.п.

В университете он читал курс, который по своему строению и объему должен был быть синтетическим изложением современных течений философской мысли, взятых с точки зрения завершения известного периода истории философии. Курс этот был озаглавлен «Критика интеллектуализма в современной философии» и охватывал обозрение всех современных антиинтеллектуалистических систем, как-то англо-американского прагматизма, французской философии чувства и действия и т.д.

В 1918 г. обстоятельства времени заставили М.Н. Ершова оставить Казань, и он поселился во Владивостоке. Летом 1918 г. по его почину возник Комитет по учреждению Историко-филологического факультета в городе Владивостоке. С осени того же года начал функционировать и сам факультет, на котором М.Н. Ершов нес большую часть работы: с одной стороны, занимая кафедру философии и сразу читая несколько основных и дополнительных курсов, с другой стороны, - будучи деканом факультета, должность, которая вследствие организационного характера всей факультетской жизни, частного характера факультета, невероятных трудностей как экономического, так и административного характера, и вообще новости всего дела требовали, помимо опыта, знания, такта, и величайшего напряжения всех сил и самоотверженной работы. В течение всего этого времени М.Н. Ершов принимал деятельное участие в организационных работах по учреждению Государственного Дальневосточного Университета - как в качестве декана и руководителя историко-филологического факультета, так и в

4 Предположительно Иаков Иакович Галахов (1865-1938), выпускник Казанской духовной академии, профессор богословия и руководитель кафедры богословия в Императорском Томском университете, настоятель университетского храма. качестве члена различных комиссий и совещаний и т.п.

Осенью 1919 г. М.Н. Ершов был избран экстраординарным профессором Государственного Иркутского Университета по кафедре философии. Однако обстоятельства времени, с одной стороны, и академические соображения, с другой, принудили его остаться во Владивостоке, где 27 апреля 1920 г. получило свое завершение то дело, которому он отдал столь много времени, энергии и здоровья. Во вновь открытом Государственном Дальневосточном Университете М.Н. Ершов был избран на должность проректора Университета.

II. Переходя к изложению и оценке ученых трудов профессора Ершова первым долгом необходимо отметить чрезвычайную экстенсивность их как в смысле многочисленности разрабатываемых проблем, широты философского кругозора и исторического освещения, так и в отношении изучения каждого вопроса со всех точек зрения, представленных в философской литературе. В этом отношении работы профессора Ершова представляют собой столь богатый материал и включают в себя столь большое количество литературных справок, что могут быть охарактеризованы, как исчерпывающие разбираемые проблемы не только в философском, но также и в библиографическом отношении. С другой стороны, - хотя философское внимание профессора Ершова и останавливалось преимущественно на некоторых проблемax (философия XVII в., антиинтеллектуализм XIX в., проблема высшего образования и быт высшей школы), тем не менее широта разбираемых вопросов, с одной стороны, и чисто исторический, экстенсивный метод, с другой привели его к чрезвычайно многосторонним работам, вследствие чего в сферу его занятий вошли почти все системы, направления и уклоны философской мысли.

В центре всех этих работ стоит диссертация профессора Ершова о философии Мальбранша, к которой примыкает целый ряд вспомогательных и дополнительных работ по тому же предмету. Уже один выбор этого малоисследованного философа, соединяющего в своей системе религиозные традиции платонизма с рационализмом XVII в. и намечающего пути имманентизму XVIII в. и XIX в., говорит нам о том круге идей, в котором вращается мысль автора; в систематическом отношении это - онтологическая и гносеологическая проблема, взятая в 
разрезе религиозного сознания XVII в.; исторически это - точка пересечения нескольких исторических процессов, в коих новая наука сплетается с древне-христианской спекуляцией, воплощаясь в чарующей своей простотой и глубиной системе Мальбранша.

Таким образом книга, озаглавленная «Проблема Богопознания в философии Мальбранша» отнюдь не является, собственно говоря, богословским исследованием. В традиционных формах официальной теологической доктрины Мальбранш излагает свою чисто философскую систему (подобно Декарту, также накинувшему на свою гносеологию богословский флер), и задача исследователя в значительной степени сводится к тому, чтобы расшифровать основные понятия системы Мальбранша и истолковать гносеологически и онтологически его доктрину «видения вещей в Боге».

Установлением этой основной проблемы и занята 1-ая глава труда профессора Ершова. Указав на то, что доктрина Мальбранша имеет своею целью обосновать своеобразный умозрительный мистицизм при посредстве рационалистического интуитивизма, автор все же ставит на первое место онтологический интерес, который у Мальбранша (в противоположность Декарту) доминирует над интересом гносеологическим. Вследствие этого и вся система, преодолевающая картезианский дуализм и сводящая все бытие и познание к их отношениям к абсолюту, характеризуется как панэнтеизм - чрезвычайно плодотворное понятие, ибо оно сближает абстрактный пантеизм с системами, строящимися на понятии трансцендентного, спасая таким образом принцип идентичности от неизбежного в противном случае имманентизма.

Переходя далее к гносеологической характеристике системы Мальбранша, автор останавливается на гносеологическом значении у Мальбранша понятия идеи. Мальбранш рассматривает идеи не только как объект познания, т.е. онтологически (а отнюдь не как его функции - психологизм, совершенно чуждый Мальбраншу), но и как формы рационального мышления, т.е. с гносеологической точки зрения. Таким образом идеи, как модификации Бога, получают значение принципов познания; доктрина «видение вещей в Боге» становится общим обоснованием гносеологии, а вся система характеризуется, как «мистицизм, стремящийся рационально обосновать свое учение о непосредственном познании Божества» (с. 35).
Установив исходные точки исследования, автор переходит к фактическим данным биографии и творчества Мальбранша. Он кратко, но выпукло описывает этого удивительного человека, «стяжавшего равную славу благочестием и философией» (слова Юма, с. 47). Упомянув о его отличительных качествах: чрезвычайной терпеливости, любви к природе и склонности к занятиям точными науками - математикой, механикой, автор характеризует Мальбранша как «солидного ученого» своего времени и глубокомысленного философа, восторженно религиозного священника Оратории (с. 51). Затем следует перечисление и краткая характеристика творений Мальбранша, которых в итоге насчитывается 13 названий.

2-ая глава рассматривает картезианские предпосылки философии Мальбранша. Среди них необходимо отметить характерное для французской науки XVII в. отрицательное отношение к схоластике и ее искусственным формам. Наука должна служить целям истинного познания, а не изощрению диалектической игры, которая в качестве «науки памяти» должна раз навсегда освободить место «науке разума». Последняя в свою очередь характеризуется чисто рационалистически. Только разумное истинно; чувственный опыт имеет скорее биологическую, чем гносеологическую ценность. Восприятие может дать только смутное и неясное познание, которое для того, чтобы быть истинным, должно быть обосновано доводами разума.

Эти требования новой науки и выполняются построением системы гносеологии, существенные элементы которой заимствованы у платонизма, и потому составляют предмет 3-й главы труда профессора Ершова, озаглавленной «Платоно-Августиновские предпосылки теории богопознания Мальбранша». Рациональное знание есть знание идей, а не вещей, которые могут быть предметом только восприятий. Идеи эти, с одной стороны, имманентны, но, с другой стороны, независимы от нашей души (в качестве предметов чисто духовных), и поэтому могут рассматриваться исключительно, как интуитивно созерцаемые сущности, как познаваемые модификации Божества.

Таким образом, получаются основные элементы доктрины «видения вещей в Боге», которая является, таким образом, необходимой предпосылкой, своеобразным гносеологическим постулатом. «Если бы мы не созерцали некоторым образом Бога, мы не видели бы ни 
одной вещи» (с. 106). Эта доктрина рождает проблемы: 1) существование конкретного мира, который объясняется при помощи теории «умопостигаемого протяжения», каковое является синтезом всякого материального разнообразия, архетипом материального мира (ибо вещи не могут быть модификациями абсолюта, который был бы в таком случае ограничен ими, но только сотворенной Им идеи протяжения); 2) проблема отношения Божества к тварному бытию, которое разрешается конструкцией панэнтеизма; согласно этому учению вселенная пребывает в Боге, который является единственным двигателем, причиной и жизненным принципом мертвой и бессильной материи (момент окказионализма), а не есть сама Бог - как об этом учил современный Мальбраншу пантеизм.

Гл. 4-я, посвященная «логике построения Мальбраншем мистической теории богопознания», дополняет гносеологическую конструкцию, изложенную в предшествующем, рассматривая четыре вида познания, которые Мальбранш различает в зависимости от их объектов. Таковыми являются: 1) непосредственное, интуитивное познание Бога; 2) диалектическое познание (при посредстве идей) нашего собственного духа; 3) дискурсивное познание (при посредстве сознания) духов, вне нас находящихся и, наконец, 4) эмпиршеское, и вследствие этого только предположительное, познание тела.

Гл. 5-я изучает влияния, испытанные философией Мальбранша со стороны августиновской (с. 164-178) и картезианской (с. 178-188) школ. К первому относятся понимание блаженной жизни как познания (а не искания) истины, принятие за исходный пункт философствования самоуглубление и внутренний анализ душевной жизни, двойственность познания (при посредстве разума и чувственного опыта) и общий интеллектуалистический характер системы. Влияние же картезианской школы, кроме общих методических принципов (о них см. выше), обнаруживается в чрезвычайно важном отождествлении бытия и идеи, которое связывает в единую систему онтологию и гносеологию (служит фундаментом онтологического доказательства бытия Божия), в общей математизирующей тенденции мышления и понимания гносеологии как методики богопознания, с той только разницей, что у Декарта понятие Бога является исходным пунктом, обосновывающим самую возможность познания, тогда как у Мальбранша - это конечная цель, которой завершается и к которой стремится все здание умозрительного мистицизма.

Заключительная глава посвящена специальному исследованию значения философии богопознания Мальбранша для целей научно-богословского мышления. Здесь система Мальбранша рассматривается в связи и сравнительно с общими традициями богословской науки и в частности с эпохой патристики II и III вв. (системы Филона Александрийского, Иустина Философа, Климента Александрийского, Оригена) и IV и V вв. (св. Афанасия Великого, Василия Великого, Григория Богослова, Григория Нисского, Дионисия Ареопагита). С этой точки зрения теория Мальбранша представляется как синтез науки и мистики и философское обоснование религии.

В заключение этого краткого обзора, должно заметить, что исследованию профессора Ершова предпослан библиографический обзор литературы о Мальбранше, где автор на 16 с. кратко рассматривает все имеющиеся труды, насчитывая всего 37 названий. Весь труд составляет 228 с. Количество упомянутых в нем сочинений (цитаты и ссылки) - 96. Количество упомянутых собственных имен - 183. В русской литературе книга профессора Ершова является единственным трудом, посвященным Мальбраншу.

Диссертация профессора Ершова была подробно рецензирована профессором Несмеловым, официальным оппонентом на его магистерском диспуте, который в весьма обстоятельной (48с.) рецензии (напечатан в «Приложении к протоколам заседаний Совета Казанской Духовной Академии» 1914 г.) указал на то, что труд этот по своей эрудиции, полноте и синтезу может быть поставлен в одном ряду с лучшими европейскими монографиями этого рода. Далее имеется рецензия профессора Саратовского Университета, известного философа С.Л. Франка, напечатанная в «Русской мысли» (1915 г. ХІ кн.), которую мы прилагаем к настоящему отзыву.

К этой основной работе о философии Мальбранша примыкает целый ряд работ, отчасти вспомогательного, отчасти самостоятельного характера. К таковым относятся: 1) «Из истории идеализма нового времени». Гносеология Мальбранша». 1911, Сергиев Посад. 1-48 с. (имеется и об этой работе отзыв Б. Яковенко в журнале «Логос») за 1912-13 гг. кн. I - II, с. 411-412. Это - чисто гносеологическая работа, большая часть которой вошла впоследствии в диссертацию. В то же время она включает однако и 
некоторые самостоятельные моменты, не подвергнутые дальнейшему развитию. К таковым в особенности относится чрезвычайно важная мысль о влиянии философии Мальбранша на систему Беркли - мысль, дающая новое освещение истории возникновения имманентизма XVIII и XIX вв., обоснование которого обыкновенно приписывалось Канту, и только после статьи Вл. Эрна (в сборнике «Борьбе за Логос») было отнесено на более раннее время и приурочено к системе английского архиепископа.

Далее следует отметить небольшую работу профессора Ершова «Умозрительно-мистические элементы в философии Мальбранша», напечатанную в «Журнале Мин[истерства] Нар[одного] Просвещения». 1915 г. № 2. Это статья, являющаяся кратким изложением содержания диссертации, составлялась из текста речи, произнесенной профессором Ершовым перед магистерским диспутом.

Гораздо большее и вполне самостоятельное значение имеет работа под заглавием «К характеристике этического учения Мальбранша», имеющая быть в ближайшее время напечатанной в «Ученых записках Историко-Филологического Факультета Государственного Дальневосточного Университета».

Этическое учение Мальбранша, чрезвычайно интересное в своих деталях, представляет исследователю большие затруднения для своего изучения и изложения. Несмотря на то, что по существу своему оно теснейшим образом связано с общей концепцией системы (блаженство то же, что познание; добро этическое - то же, что истинная мудрость; след[овательно], этика в конечных целях совпадает с гносеологией), тем не менее теория нравственности Мальбранша представляется раздробленной не только вследствие того, что этические замечания разбросаны у него по всем сочинениям, сколько потому, что сама этика является двойственной. С одной стороны, Traité de l'amour de Dieu ${ }^{5}$, pacсматривающий любовь к Богу, как стремление к совершеннейшему блаженству, может быть охарактеризован как своеобразная система рационалистически-утилитарной этики. Ибо если человек, как существо относительное, стремится к Абсолюту, чтобы обогатиться от него бо-

\footnotetext{
5 Здесь и далее латиницей передан вписанный от руки текст по неполному экземпляру документа из другого дела (РГИА ДВ. Ф. Р-289. Оп. 1. Д. 73. Л. 2-16). В публикуемом варианте Отзыва на этих местах оставлены пробелы.
}

жественным содержанием истинного познания, то стремление это ни в коем случае не может быть названо незаинтересованным. Наоборот, оно представляется своекорыстным, хотя и в лучшем, наиболее возвышенном смысле этого слова (ср[авни] афоризмы Ла-Рош-Фуко о дружбе). Но этой концепции этики противополагается «Traité de morale», обосновывающий добродетель чисто онтологически. Единственной добродетелью, согласно этой точки зрения, является господствующее природное стремление к непреложному порядку. Именно порядок, как активное проявление божественного принципа, а не истина, которая есть только его спекулятивный аспект, является основным принципом нравственности. В этом смысле он противополагается не только обеспорядоченной /dereglée/ природе с ее страстями, которые суть не что иное, как проявление хаотического начала множественности, но и вообще понятию удовольствия (даже духовного), поскольку оно предполагает, что его носитель существует отдельно и независимо от того Абсолюта, к которому он должен стремиться.

Наконец, из цикла работ профессора Еpшова о Мальбранше необходимо отметить его перевод с французского «Беседы христианского философа с философом китайским о бытии и природе Божества» (Казань, 1914 г. с. 47). Этот небольшой трактат Мальбранша, являющийся полемикой против вышедшего из недр конфуцианства учения о самостоятельности двух коррелативных начал: Ци и Ли (материи и Божества), имеет весьма большое значение, с одной стороны, для преодоления дуализма (в частности картезианского), а с другой - для предупреждения опасности уклонения в манихейство, опасности, всегда угрожающей радикальному дуализму платоновского типа. Профессор С.Л. Франк, рецензируя диссертацию профессора Ершова, коснулся и этого трактата, отметив качества перевода и выразив надежду, что этот перевод будет не последним, вышедшим из-под пера М.Н. Ершова.

В области современных философских течений внимание профессора Ершова привлекли к себе антиинтеллектуалистические доктрины как англо-американского, так и, в особенности, французского типа, а также связанные с ними уклоны неокатолической мысли во Франции. И если историко-философские работы профессора Ершова богаты литературными ссылками и библиографическими указаниями, то полно- 
та собранного материала и эрудиция автора в сложных и запутанных течениях современной мысли должны обратить на себя особое внимание читающего. Статья «Антиинтеллектуалистическое движение в современной философии $(\mathrm{I}-20$ c.)» рассматривает философскую мысль $\mathrm{XX}$ в. как критическую реакцию на господствовавший в течение всей новой философии интеллектуализм, получившей свое полное развитие в немецком идеализме и возобновленный в настоящее время в некоторых течениях неокантианства. Указав на то, что протест против тираннии разума встречается еще у Вл. Соловьева («Кризис западной философии»), автор переходит к обзору трех уклонов философской мысли, в которых антиинтеллектуалистические тенденции сказываются с особой силой. Сюда относятся: 1) философия, ориентирующаяся на понятии ценности и ставящая свей последней задачей обоснование культуры (Вильгельм Виндельбанд, Генрих Риккерт, Рудольф Эйкен, Геральд Геффдинг, Гуго Мюнстерберг).

2) религиозная философия, поскольку она получила развитие в трудах Эмиля Бутру, Гура, Ле-Руа, Джемса, Ледда, Эйкена, Геффдинга.

3) новые течения в гносеологии как типа интуитивного (Бергсон, Франк, Ле-Руа, Блондель), так и прагматического (Джеймс, Шиллер, Дьюи). Процесс разочарования в интеллектуализме следует, согласно автору, рассматривать не изолировано, но в связи со всей умственной историей нового времени, в частности в связи с поэзией, из каковой и заимствованы удачно подобранные примеры (Буало, Верлэн и Ришпэн).

Этим же вопросам, хотя и в несколько в ином разрезе, посвящена большая статья профессора Ершова «Проблемы религиозно-философской мысли в современной Франции» (Казань, 1916. I-49 с.).

Отметив предварительно антиинтеллектуалистические тенденции современной французской мысли в лице Бергсона, Лаланда, Пароди, Ле-Дантека, Бэло, Буарака, Дюма, Делакруа, Моно, Люази, Дюркгейма, Двельзгоэера, Бруншвика, Ле-Руа, Бутру, и дав краткую характеристику тех работ, которые предпринимались в этом отношении (Серии лекций и докладов, организованных École libre des hautes études в 1912-13 гг. и журналом Foi et Vie), автор переходит к изложению и оценке сборника «Цельное Знание», вышедшего при участии Э.Л. Радлова в Петрограде в 1915 г. Автор подробно останавливается на статье Милорадович «Главнейшие течения религиозно-философской мысли в современной Франции», на помещенном в сборнике переводе последней главы книги A. Sabatier «Esquisse d'une philosophie de la religion», где в качестве основных религиозных категорий полагаются моменты субъективизма, целесообразности и символизма, на статье E. Le Roy «Как следует ставить проблему Бога» и, наконец, на переводе энциклики Папы Пия X - Pascendi Dominici gregis, направленной против модернистов и развивающей энциклику Aeterni Patris (1879), положившей в современной философской литературе начало сильному движению неотомизма. Подводя итоги всем рассмотренным сочинениям, автор устанавливает три течения современной религиозной мысли во Франции: протестанствующее направление, движущееся в рамках, связанными с именами Кант-Ричль; сюда относится глава французского неокантианства Шарль Ренувье, у которого неокритицизм обращается в персонализм, и Сабатье, с ярко выраженными индивидуалистическими тенденциями в сфере философии религии; 2) философия чувства и действия, представителями которой в религиозной области являются Ле-Руа, Равессон, Секретан и Менегаза, стремящиеся к удовлетворению запросов целостной личности и, наконец, 3) ультрамонтанское течение, представленное некоторыми французскими (а также и немецкими) учеными и журналами узкого томистического направления.

К этим работам примыкает незаконченный пока перевод труда J. Gourd'a «Philosophie de la religion», подготовляемый профессором Ершовым для печати. Гур (профессор Лозанского Университета) - неогегельянец, и его труд в области философии религии является особенно интересным, потому что представляет собою чисто философское - гносеологическое и онтологическое исследование, совершенно свободное от психологических и антропологических наслоений, которыми эта область философии систематически засорялась в течение всего XIX в.

Статья профессора Ершова «К характеристике суждений о русской философии» (I-16 с.) посвящена анализу работы Seliber'a, La pensée russe présente-t-elle des tendances originales en philosophie (Revue philosophique, 1914, № 8-9). Эта работа чрезвычайно интересна в том отношении, что знакомит французское общество с историей русской философской мысли и знакомит притом чрезвычайно основательно и авторитетно. Г[осподин] Селибер не только пре- 
красно ориентирован в русской философии, но и лично находится в связи с некоторыми философскими кругами России, что дает ему возможность сделать обзор интересный не только для иностранцев, но и для русских. Между тем, его работа остается совершенно неизвестной в России, и статья профессора Ершова имеет целью обратить на нее внимание русской читающей публики, дав одновременно ее философскую оценку. Рассматривая русскую мысль в сравнении с европейской, Селибер видит в ней следующие характерные моменты и направления: 1) искажение конкретного идеала (у Вл. Соловьева, С.П. Трубецкого) и 2) тенденции социальной морали (Михайловский, Лавров); 3) конкретный спиритуалистический идеализм и творческая причинность (Л.М. Лопатин, М. Каринский, А.А. Козлов, С.А. Аскольдов); 4) борьба против индивидуализма (С.Н. Булгаков, Н. Бердяев, Н.О. Лосский). При крайней бедности литературы по истории русской философии, статья г[осподина]. Селибера приобретает значительный интерес и для русских читателей.

Статья профессора Ершова «Новый опыт обоснования спиритуализма в русской философской литературе (I - 11 с.)» является рецензией на диссертацию В.С. Шилкарского «Типологический метод в истории философии» I т. Юрьев, 1916. Указав на то, что спиритуализм не является новым для русской философии и что направление, которого придерживается автор, уже неоднократно было обосновываемо русскими авторами, продолжающими традицию, которую можно обозначить вехами: Лейбниц-Лотце-Тейхмюллер, профессор Ершов весьма сурово осуждает автора за те недостатки (чрезмерная цитация, монографический характер систематического сочинения), которые делают его диссертацию несущественной с внутренней стороны и неудобочитаемой со стороны внешней.

Одному из представителей русской философской мысли профессор Ершов посвятил специальный этюд в Харьковском журнале «Вера и разум» (1910 г., №№ 14 и 15).

Статья озаглавлена «К характеристике философских взглядов М.М. Троицкого» (I - 48 с.). M.M. Троицкий († 1899 г.), профессор Московского Университета, известен как автор трех значительных трудов: «Немецкая психология в текущем столетии» (I-II т.), «Наука о духе» (I-II т.т.) и «Учебник логики» (I-III т.т.). M.M. Троицкий известен как последова- тель и поборник идей английского эмпиризма на русской почве (его ученики - профессор А.И. Смирнов, Ф.А. Зеленогорский, А.И. Белкин, Вл. Н. Ивановский). Труд М.М. Троицкого «Немецкая психология», вышедший в начале 60-х годов прошлого столетия, вызвал большую литературную полемику в силу своего отрицательного отношения к немецкому идеализму (Канту, Фихте, Шеллингу, Гегелю). Профессор М.Н. Ершов дает интересную оценку и литературному спору, в свое время поднявшемуся вокруг «Немецкой психологии», и вообще всей философско-литературной деятельности М.M. Троицкого.

Профессиональный интерес к вопросам академического преподавания вызвал продолжительное изучение профессором Ершовым вопросов организации и быта высшей школы, которое имело своим результатом интересную статью: «Факторы культурного развития личности» (педагогический этюд), имеющую быть напечатанной в «Ученых записках Историко-филологического Факультета Дальневосточного Университета». Автор задается первым долгом вопросом, в чем заключается культура, распространению которой служит высшая школа, и, учитывая учение Риккерта, Несмелова и Струве-Франка, определяет ее как «динамический процесс, зиждующийся на том, что объективные образования, не теряя своей объективности, вовлекаются как пути и как средства во внутренний процесс работы человеческого сознания, стремящегося к реализации абсолютных ценностей». Вследствие этого и школа может служить культуре, с одной стороны, путем образования и сообщения известного комплекса знаний (интеллектуальные процессы), а с другой - путем воспитания в определенных идеалах (социальное воспитание Платона - Наторпа). Высшая школа имеет кроме этого своей задачей хранение и теоретическую разработку научных и культурных ценностей. С этой точки зрения профессор Ершов выступает с требованиями широкой унитарности и гуманитарности образования. Переходя к собственной части своего исследования, автор подробно останавливается на так называемом «споре о новой Сорбонне», в котором наиболее рельефно выразились современные притязания специальных дисциплин секуляризировать высшую школу и столь же громко прозвучал голос традиции, не удовлетворяющийся техникой, но требующей теории как единой чистой науки во имя человечности. 
В завершение этого обзора необходимо сказать несколько слов о профессоре Ершове, как о преподавателе и академическом работнике. Профессор Ершов более всего историк; поэтому его лекции носят чисто объективный и строго научный характер, не влияя на слушателей в том или ином направлении, но знакомя их со всей областью философии и предоставляя каждому выбирать для дальнейшей работы то, что соответствует его вкусам и наклонностям. Эта строгая объективность является особенно ценным и редким качеством среди профессоров философии, вследствие того, что самый характер этой науки легко ставит в зависимость от личного мировоззрения философа даже историческое изложение мысли прошлых веков (ср., например, Паульсона, Бундта). Работая же у профессора Ершова, слушатель никогда не знает, какому направлению отдает предпочтение его руководитель, ибо находит в нем не проповедника той или иной истины, но объективного судью и строгого исследователя истории человеческой мысли. Эти качества ученого и педагога, соединенные с огромной эрудицией, делают из М.Н. Ершова прекрасного руководителя не только в смысле богатства сообщаемого слушателям материала и авторитетности указаний, но и в отношении предоставления слушателям внутренней свободы развития, соединенной однако со строгими требованиями высшего философского образования. Требования, предъявляемые профессором Ершовым как к студентам, так к академическим работникам вообще, являются результатом не только личной его любви и понимания жизни высшей школы, но и практическим выводом из того философского миропонимания и культурного жизневоззрения, которое ставит своим фундаментом широкое гуманитарное развитие личности (ср. его работы о высшей школе).

Подводя итоги всему вышесказанному, мы должны отметить, что ученая работа профессора Ершова не только выделяет его как самостоятельного исследователя и талантливого историка в число редких специалистов даже в такой области, как философия, но отличается некоторыми особенностями, делающими его сочинения особенно ценными и значительными для нашей науки. Таковой является уже упомянутая библиографическая полнота и богатство литературных ссылок и указаний, отличающая все работы профессора Ершова, и не только придающая им значение исчерпывающих исто- рико-философских исследований, но всегда расширяющая рамки монографии или статьи за пределы данного вопроса и ставящая их в связь со всей эпохой.

Вследствие этого очерки, посвященные отдельным вопросам, приобретают общекультурное значение и тем восполняют тот систематический философский элемент, который сам по себе представлен в работах профессора Ершова значительно слабее исторического. С другой стороны, необходимо отметить своеобразие и оригинальность выбираемых автором тем. Начиная с малоисследоваемого Мальбранша и кончая новейшими проявлениями неотомизма все изучаемые профессором Ершовым направления мысли отличаются, кроме своих внутренних качеств, одной особенностью. Знание о них мало распространено на Западе и совершенно чуждо России. Поэтому работы профессора Ершова всегда открывают новые перспективы и знакомят читателя с новыми для него мыслями, которые может быть оставались для него незамеченными вследствие своей изысканной особенности, оправдывая слова Спинозы, что «все прекрасное столь же трудно, сколь резко».

III. Список трудов профессора М.Н. Ершова:

1. К характеристике философских взглядов М.М. Троицкого. Журнал «Вера и разум». 1916. №№ 14 и 15 .

2. Из истории идеализма нового времени. Гносеология Мальбранша. Сергиев Посад, 1911 г.

3. Проблема богопознания в философии Мальбранша. Казань, 1914. 228 + 1-II стр.

4. Мальбранш. Беседа христианского философа с философом китайским о бытии и природе Божества. Пер. с французского. Казань. 1914.

5. Умозрительно-мистические элементы в философии Мальбранша. Журн[ал] М[инистерст]ва Нар[одного] Просв[ещения]. 1915, Февраль.

6. К характеристике суждений о русской философии. Журн[ал] Православн[ый] Собеседник. Издание Казанской Духовной Академии, 1915. Декабрь.

7. Проблемы религиозно-философской мысли в современной Франции. Казань, 1916.

8. Новый опыт обоснования спиритуализма в русской философской литературе // Уч[еные] Зап[иски] Истор[ико-]Филолог[ического] Факульт[ета] во Владивостоке. Т. І. отд. II . вып. 2.

9. Анти-интеллектуалистическое движение в современной философии. Там же. Т. І. отд. I . вып. 1. 
10. Ряд рецензий (числом 3) на кандидатские студенческие сочинения, напечатанных в «Приложениях к протоколам заседаний Совета Казанской Духовной Академии за 1913 -14 гг.».

Кроме того, 9 рецензий и один отзыв о докторской диссертации остаются пока не напечатанными // Там же за 1915-17 гг.

Ряд газетных статей по вопросу об организации высшей школы во Владивостоке:

«О высшем учебном заведении во Владивостоке» // «Голос Приморья». 1918. № 260.

«Запросы и нужды Высшего образования на Д[альнем] В[остоке]» // Приморская жизнь. 1918. № 1.

«К учреждению Государственного университета» // «Голос Приморья». 1919. № 529.

Кроме того, готовы для печати:

11. К характеристике этического учения Мальбранша. / - 47 с. (рукопись).

12. Факторы культурного развития личности (педагогический этюд). / - 59 с. (рукопись).
Готовятся к печати:

Перевод книги ${ }^{6}$

приготовлена рукопись в 141 стр. (размер обычного писчего листа).

На основании всего вышеизложенного и имея в виду пункт 5-й ст. 3 «Временного положения о Государственном Дальневосточном Университете», мы имеем честь предложить факультету возбудить ходатайство через Совет Университета перед Временным правительством о назначении профессора М.Н. Ершова и.д. ординарного профессора по кафедре философии.

РГИА ДВ. Ф. Р-289. On. 1. Д. 97. Л. 3-12об.

${ }^{6}$ Видимо, книги, указанной выше: перевод работы Ж.-Ж. Гура.

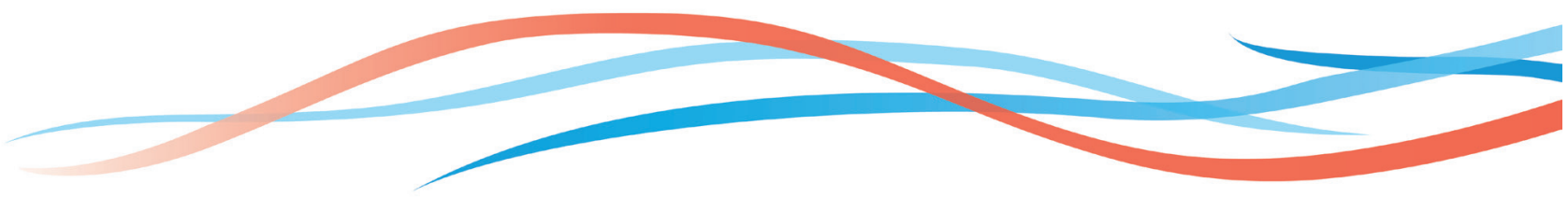

